work in biology, three are general discourses on bionics or on some broad aspect of it, nine are concerned with mathematical treatments of specific biological problems, nine provide a mathematical study of some more general biological situation, nine deal with the design of artefacts or practical models or are concerned with the simulation of a biological process and the remaining five extend the theory of nerve networks. The biological problems studied are equally varied and in addition to the comparatively large number of papers on vision, audition and various aspects of the functioning of nerves and nervous pathways, there are papers on taste, enzyme synthesis, epidemiology, the shapes of leaves and the development of the chick embryo.

Of the more practical papers mention must be made of the partially successful attempt by A. J. Cote, jun., to derive from the Pandemonium of Selfridge a machine to interpret radar displays and of the design studies made by K. H. Reid in order to apply conditional probability com. puters to the control of chemical processes. The possibility of constructing digital computers containing $10^{9}$ active elements within a $10-\mathrm{ft}$. cube is discussed by Levy and Schuller, who base their arguments on a transistor with an active area of $10^{-4} \mathrm{~cm}^{2}$ and a dissipation of $10^{-6} \mathrm{~W}$.

On the theoretical side Smith and Davidson have considered the total activity in a neural network and have extended the results of earlier workers. In two long and interesting papers, $H$. Blum develops a new approach to the coding or processing of sensory data and L. Lofgren outlines a theory of 'self-repairing' automata. These and other papers deserve a full discussion; but this review must conclude by recommending this volume to engineers and others interested in bionics and hoping that enough biologists will read it for the biological content of the next symposium to be increased substantially.

$$
\text { J. T. Altanson }
$$

\section{TROPICAL FLORAS IN THE TERTIARY IN SOUTHERN ENGLAND}

The Lower Tertiary Floras of Southern England

By Marjorie Elizabeth Jane Chandler. 2: Flora of the PipeClay Series of Dorset (Lower Bagshot). Pp. xi $+176+29$ plates. (London: British Museum (Natural History), 1962.) 168s. net.

I $N$ this second volume of Miss Chandler's important 1 work on The Lower Tertiary F'loras of Southern England, of which the first volume was reviewed in Nature (195, 209 ; 1961), she describes the large collections of fossil plants, principally seeds and fruits of Angiosperms, which with much labour she has collected from the Lower Bagshot beds of Dorset and Hampshire and prepared for examination and description. This heavy work was necessary because the collections made by previous investigators are for the most part valueless since the localities and horizons had not been recorded on the specimens.

While the largest number of taxa have been found in the sandy beds of the Pipe Clay Series in localities at Lake and Arne in Dorset the oldest beds of the Lower Bagshot occur in the cliffs at Studland. The specimens of seeds and fruits are carbonized and have not suffered serious compression, but compared with the fossils described in the London Clay Flora, which are largely pyritized, the preservation of tissues is much poorer.

The lowest beds, those at Studland, have furnished a small number of genera, including Acrostichum, Lygodium, Sequoia, Ficus, Burtonella and Rubus. With the flora of the sandy beds of the Pipe Clay Series the natural orders in the Lower Bagshot beds number about forty, of which twenty-three are characteristic of present-day tropical or subtropical forests. There are, for example, fourteen species of vines (Vitis) while Euphorbiaceae and
Cornaceae are well represented by genera and species. Other orders represented are Burseraceae, Anacardiaceae, Ebenaceae and Symplocaceae. Unfortunately the beds from which many of the specimens were derived at Lake and Arne are now threatened by eliff falls or camp-site developments. However, Miss Chandler has amassed sufficient evidence to make it certain that the flora was that of a tropical forest region, with a somewhat warmer climate than that of the preceding London Clay flora, with evidence of the proximity of rivers and in places saline conditions favouring the growth of Acrostichum similar to those under which $A$. aureum grows in the tropics to-day.

This volume shows the same high standard of production as the first of the series and we have to thank Miss Chandler for another most important addition to the knowledge of Tertiary floras.

JOHN WALTON

\section{SCHIMPER'S 'PLANT GEOGRAPHY' REBORN}

Die Vegetation der Erde in Ökologischer Betrachtung Von Prof. Heinrich Walter. Band 1: Die Tropischen und Subtropischen Zonen. Pp. $x v+538+9$ tafeln. (Jena: Gustav Fischer Verlag, 1962.) 68.10 D.M.

WHEN it was suggested that he should prepare a now edition of Schimper's Plant Geography Prof. H. Walter decided, no doubt rightly, that the task was impossible and that it would be necessary to write an entirely new book.

There are few botanical text-books better known or better loved than 'Schimper'. Originally published in German in 1898, it became available in English through W. R. Fisher's translation, which was revised and edited by Percy Groom and I. Bailey Balfour and published by the Clarendon Press in 1903, two years after the author's death. Ever since, the book in either the German or the English version, has been an indispensable part of every botanical library; even to-day few plant geographers would care to be without it. In 1935 a new German edition was published (called the third, though in fact the second was merely a reprint of the first), edited by F. C. von Faber. This contained much additional material and was notable for the large number of excellent photographs, many of them taken from that rich store of vegetation pictures, Schenk and Karsten's Vegetationsbilder.

When a further edition was called for, the decision to start afresh was wise as well as courageous, for nobody could have brought 'Schimper' up to date without destroying the character of the original; even in the 1935 edition the additions were not altogether happily grafted on to the original text.

The new book is planned on monumental lines: the present volume of 538 pages, dealing with the vegetation of the tropics and sub-tropics, is to be followed by another on the rest of the world and after this seven 'vegetation monographs' are contemplated dealing with the vegetation of the various continents.

The introductory chapter, which forms the theoretical basis of the whole work, expounds the basic ideas of modern plant ecology-the concept of the plant community, the effects of competition on the ecological range of species, the zonation of climate, climatio soil typos, succession and the theory of the climax, etc. On the plant community Prof. Walter takes a middle course between the views of those like Clements, Tansley and Braun-Blanquet who think that plant communities are discrete and objectively definable units and those of Gleason and others who regard all vegetation as continua. It is noteworthy that Schimper's old (and at the time valuable) distinction between 'climatic formations' and 'edaphic formations' is replaced by a division into 'zonal', 'azonal' and 'extra-zonal' vegetation. 